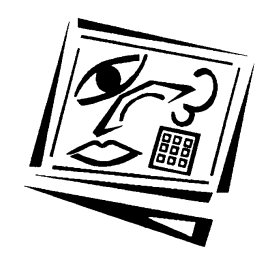

\title{
MAGDAIRE: A model to foster pre-service teachers' ability in integrating ICT and teaching in Taiwan
}

\author{
Chun-Yen Chang, Yu-Ta Chien, Yueh-Hsia Chang and Chen-Yung Lin \\ National Taiwan Normal University
}

\begin{abstract}
This report describes our efforts in fostering Taiwanese pre-service teachers' ability to integrate information and communication technology (ICT) and teaching. The current state of science teacher education and ICT policies in Taiwan are documented briefly. The course model, MAGDAIRE (abbreviated from Modeled Analysis, Guided Development, Articulated Implementation, and Reflected Evaluation) is then introduced to counterbalance the insufficiency of the current teacher education courses in Taiwan. The model is subsequently employed to enhance a science teacher education course at National Taiwan Normal University (NTNU). The study conducted along with the course indicates that MAGDAIRE can significantly improve pre-service teachers' ICT knowledge and skills. Moreover, MAGDAIRE can significantly enhance pre-service teachers' sensitivity to the complex interactions between ICT, pedagogy, and subject matter. Some recommendations for employing the proposed model to enhance teacher education courses are discussed.
\end{abstract}

\section{Introduction}

Educating all pre-service primary and secondary teachers in the use of information and communication technology (ICT) to enhance teaching has become a social commitment and an important objective for all teacher education programs in Taiwan. In 2005, the Ministry of Education (MOE) in Taiwan enacted the project Establishing ICT Literacy Standards for Primary and Secondary Teachers (MOE, 2008a). The project argued that a modern teacher in this digital age must know how to utilise ICT for enhancing instructional planning, teaching, assessment, and classroom management. It was expected that, by the end of 2011, more than $90 \%$ of primary and secondary school teachers would have implemented ICT-integrated curriculums into their classrooms (MOE, 2008b). In order to meet this demand, the Primary and Secondary School Information Education White Paper (MOE, 2008b) further emphasised the need to initiate training programs to build up pre-service teachers' ICT capacity for teaching.

However, there has been little pedagogical innovation to reframe ICT-related courses for teacher education programs. The course list, issued by MOE for all teacher education programs, has not been updated since 2004. As shown in Table 1, only one ICT-related course can be found on the list of required courses; the course is called Instructional Media, in the field of instructional methods. However, pre-service teachers are asked to take only three courses out of the six courses in the field of instructional methods. Thus this ICT course has to compete with other courses for survival within the same field, including Principles of Teaching, Classroom Management, Educational Assessment and Evaluation, Theory and Practice in Counseling, and Curriculum 
Development and Design. In essence, ICT knowledge and skills are optional rather than fundamental requirements for pre-service teachers. Besides, the focus of Instructional Media is to train pre-service teachers in multiple ICT skills at a time, such as the use of word processing, spreadsheet, the Internet, and presentation tools. As observed by Angeli (2005), the role of ICT in this type of training is regarded as the content to be learned, rather than the tool to enhance teaching. As a result, pre-service teachers may lose sight of how ICT tools can be aligned with appropriate pedagogies for teaching.

Table 1: Education courses issued by the Ministry of Education in Taiwan

\begin{tabular}{|c|c|c|c|}
\hline Field & Courses & Credit hours & Remark \\
\hline \multirow{4}{*}{$\begin{array}{l}\text { Foundations of } \\
\text { education }\end{array}$} & Introduction to Education & 2 & \multirow{4}{*}{$\begin{array}{l}\text { Enrol in } 2 \\
\text { courses }\end{array}$} \\
\hline & Educational Psychology & 2 & \\
\hline & Sociology of Education & 2 & \\
\hline & Philosophy of Education & 2 & \\
\hline \multirow[t]{6}{*}{ Instructional methods } & Principles of Teaching & 2 & \multirow{6}{*}{$\begin{array}{l}\text { Enrol in } 3 \\
\text { courses }\end{array}$} \\
\hline & Classroom Management & 2 & \\
\hline & Educational Assessment and Evaluation & 2 & \\
\hline & Theory and Practice in Counseling & 2 & \\
\hline & Curriculum Development and Design & 2 & \\
\hline & Instructional Media & 2 & \\
\hline \multirow[t]{2}{*}{ Teaching practicum } & Teaching Materials and Methods & 2 & \\
\hline & Practicum & 2 & \\
\hline Optional & Around 20 courses & 2 for each & $\begin{array}{l}\text { Enrol in 6-7 } \\
\text { courses }\end{array}$ \\
\hline
\end{tabular}

The mastery of ICT knowledge and skills has been recognised as a significant and fundamental factor contributing to the implementation of ICT-integrated teaching in previous studies (e.g., Govender \& Govender, 2009; Mahdizadeh, Biemans \& Mulder, 2008; Sørebø, Halvari, Gulli \& Kristiansen, 2009). However, in order to effectively enhance students' learning outcomes through ICT-integrated teaching, teachers need to further understand the interaction between the use of ICT, teaching pedagogies (Chang, 2003), students' characteristics (Chang \& Tsai, 2005), and features of subject matter (Chien \& Chang, 2012). In other words, any successful ICT-integrated teaching requires a comprehensive understanding of the mutually reinforcing relationships between technological knowledge, pedagogical knowledge, and content knowledge (Angeli \& Valanides, 2009; Chien, Chang, Yeh \& Chang, 2012; Lee \& Tsai, 2010; Jang \& Chen, 2010; Koehler, Mishra \& Yahya, 2007; Mishra \& Koehler, 2006; Niess, 2005). Mishra and Koehler (2006) proposed the Technological Pedagogical and Content Knowledge (TPCK or TPACK) framework to conceptualise such relationships. In order to implement effective ICT-integrated teaching, teachers need to understand the dynamic interplays between how a subject matter might be shaped by the application of ICT (i.e., technological content knowledge), how teaching as well as learning might be changed by the use of ICT (i.e., technological pedagogical knowledge), and how to represent and communicate specific concepts and topics of a subject matter to students (i.e., pedagogical content knowledge).

However, the three fundamental elements of ICT-integrated teaching (i.e., ICT, pedagogy, and content) are fragmented and thus separated in different courses of the current teacher education program in Taiwan. As indicated by Jang and Chen (2010), pre-service teachers in Taiwan acquire content knowledge from discipline courses of 
their colleges and gain pedagogical knowledge from education specialisation courses offered by teacher education programs, respectively. They then, may patch up multiple ICT knowledge and skills from the Instructional Media course. This approach is irrelevant to the development of either pre-service teachers' content knowledge or pedagogical knowledge. Such an approach has been criticised for its failure to correlate teachers' ICT knowledge and skills with their teaching (Angeli, 2005; International Society for Technology in Education, 2008; Jang, 2008; Jang \& Chen, 2010; Koehler et al., 2007; Niess, 2005; Organization for Economic Cooperation and Development, 2010; Wilson, 2003). A pragmatic approach to build up pre-service teachers' ICT capability for teaching is to provide them with a meaningful context in which ICT can be pedagogically situated in the teaching of subject matter (Angeli \& Valanides, 2009; Chien et al., 2012; Enochsson \& Rizza, 2009; Jang \& Chen, 2010; Koehler et al., 2007).

Therefore, we built a course model based on the learning technology by design approach (Koehler et al., 2007; Mishra \& Koehler, 2006) to enhance a science teacher education course in Taiwan. As stated by Koehler et al. (2007; p. 744), learning technology by design means that "teachers work collaboratively in small groups to develop technology-rich solutions to authentic pedagogical problems, and accordingly, they learn about technology and pedagogy by actually using and designing educational technology to teach specific content." Beyond involving pre-service teachers in designing ICT-based lessons, we further engage pre-service teachers in implementing and then revising their ICT-based lessons. This process moves pre-service teachers from the roles of passive users of ICT into active designers, content providers, and teaching practitioners of ICT-integrated lessons. By this means, the course is contextualised with the rich interplays between ICT, pedagogy, and content. The aims of the course model are to equip pre-service teachers with ICT knowledge and skills and to facilitate their development of TPACK.

\section{A model to enhance a pre-service science teacher education course}

In the course model, Adobe Flash is chosen as the tool to develop ICT-based lessons. The reasons are as follows: (1) Flash can help teachers to compile static images into dynamic animation forms through automatic procedures. Scientific phenomena, which are too small, large, fast, or slow to be observed or experienced directly with the unaided human senses, may be displayed in this way; (2) Flash allows teachers to add interactive functions into animations to enable students to manipulate the visualisations or models. It helps teachers to build tools to assist students in visualising, sharing, and testing their hypotheses to explain scientific phenomena; (3) Flash enables animations to record, retrieve, and exchange users' information on the Internet. It benefits teachers in collecting students' data, in terms of learning processes as well as assessments; (4) Flash-made content has reached $99 \%$ of Internet viewers (Adobe, 2010). Students and teachers can easily access any Flash-based resources both inside and outside of schools. The aforementioned features of Flash allow pre-service science teachers to customise ICT-based lessons to fit their teaching practices.

The use of Flash to build and implement the ICT-base lessons is simply one example of pre-service teachers' ICT competency. In this paper, the development of the pre-service teachers' pedagogical reasoning on the integration of Flash and teaching is thus specified as the development of "Technological Pedagogical and Content Knowledge - Flash (TPACK-F)". Based on our previous study (Chien et al., 2012), we draw on Collins's 
(1988) cognitive apprenticeship to scale up a 4-phase cyclic MAGDAIRE model (abbreviated from Modeled Analysis, Guided Development, Articulated Implementation, and Reflected Evaluation). The use of cognitive apprenticeship aims to facilitate pre-service teachers to learn conditions for applying TPACK-F, see the implications of TPACK-F, and make inventions and apply their TPACK-F to capture the general features of teaching involved in classroom contexts, including complexity, uncertainty, instability, uniqueness, and value conflict (Clark \& Yinger, 1987). The framework of MAGDAIRE can be seen in Figure 1; each phase of MAGDAIRE is described below in more detail.

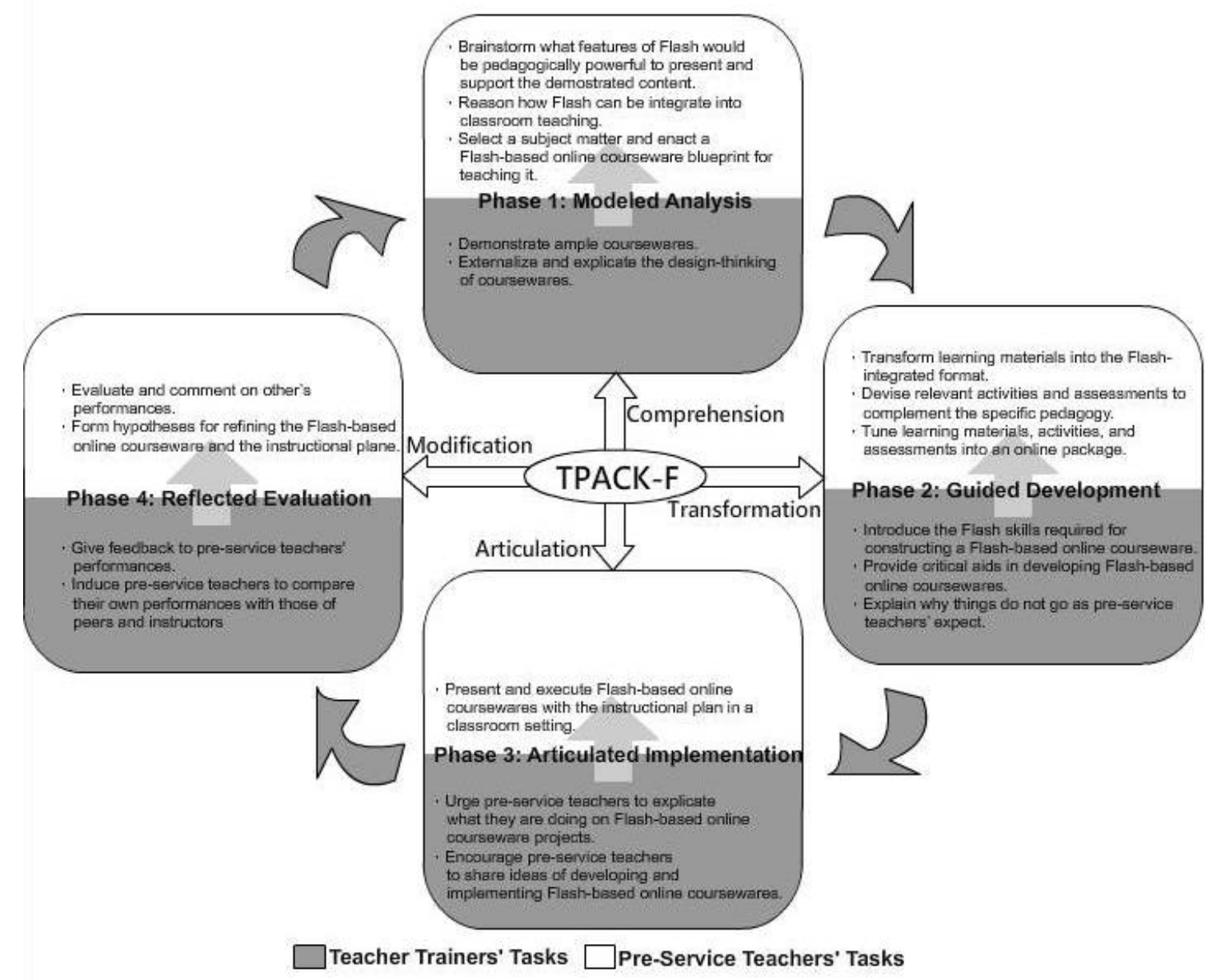

Figure 1: MAGDAIRE model (revised from Chien et al., 2012)

\section{Phase I: Modeled analysis}

Pre-service teachers are divided into sub-groups. Teacher trainers demonstrate ample Flash-based online courseware of their own design. They then explain the design thinking underlying their courseware, for peers to observe and imitate. In this phase, the modeling facet of Collins's cognitive apprenticeship is applied to facilitate their 
comprehension of TPACK-F. The modeling of instructors' performances and design thinking aims to enable pre-service teachers to brainstorm what features of Flash would be pedagogically powerful to present and support the chosen content; and how Flash may be integrated into classroom teaching. Each group then selects a science topic; they then enact their Flash-based online courseware blueprints for teaching the science topic.

\section{Phase II: Guided development}

Teacher trainers introduce the Flash concepts and skills required for constructing a Flash-based online courseware to pre-service teachers. Each group then tries to transform the learning materials of the chosen subject matter into a Flash-integrated format. The next step is to devise relevant activities as well as assessments to complement the pedagogies they plan out. Thereafter, each group tunes the learning materials, activities, and assessments into an online package. In this phase, the coaching and scaffolding facets of Collins's cognitive apprenticeship are applied to facilitate pre-service teachers to transform TPACK-F into artifacts to solve authentic pedagogical problems. Teacher trainers provide pre-service teachers with critical aids in transforming their topic, learning activities, and assessments into a Flash-integrated format. Teacher trainers further suggest or provide solutions to the problems preservice teachers encounter. As the pre-service teachers gain more expertise, teacher trainers gradually push them to think and work more independently.

\section{Phase III: Articulated implementation}

Pre-service teachers are asked to present and execute their Flash-based online courseware along with their instructional plans in a classroom setting. In this phase, the articulation facet of Collins's cognitive apprenticeship is applied to facilitate preservice teachers to articulate their tacit TPACK-F in teaching practice. Teacher trainers induce pre-service teachers to explain their intentions and reasons for every step they perform. This process forces the pre-service teachers to think about what they are doing on Flash-integrated teaching. Thus, they must make their tacit thoughts explicitly clear. This also enables them to experience others' perspectives on Flashintegrated instruction in the same context and across different contexts.

\section{Phase IV: Reflected evaluation}

Pre-service teachers are asked to compare their own performances with those of peers and teacher trainers, and then give comments on others. In this phase, the reflection and exploration facets of Collins's cognitive apprenticeship are applied to facilitate pre-service teachers to modify their TPACK-F. Each pre-service teacher reflectively researches what elements are critical to successful and unsuccessful Flash-integrated teaching. Moreover, the comments from peers function as a replay for analysis. Instructors further encourage pre-service teachers to form hypotheses for refining their Flash-based online coursewares and instructional plans. The reflected evaluation phase takes place as the formative assessment. It prompts pre-service teachers to deliberate and experiment. They are obliged to share the manner in which the subject matter and teaching/learning processes might be shaped by the application of Flash in the next cycle of MAGDAIRE. 
While the context of MAGDAIRE predetermines the production and implementation of Flash-based online courseware as the solution to the pre-service teachers' instructional problems, it allows them to explore various pedagogies with respect to their subject matters. Our previous study in a similar context (Chien et al., 2012) found that pre-service science teachers held different views of teaching when they entered the context of MAGDAIRE. These different instructional orientations were reflected in their Flash-based lessons, such as transmission-orientation and the constructivistorientation. Through inspecting peers' performances on Flash-based lessons within the context of MAGDAIRE, the pre-service teachers revised their courseware and instructional plans to improve the efficiency of their Flash-integrated teaching practices. It was observed that, in order to negotiate the ideal Flash-integrated instruction with actual classroom settings, the pre-service science teachers' Flashintegrated pedagogies transited between transmission-orientation and constructivistorientation, such as linear learning pacing versus nested learning pacing, noninteractive activities versus interactive activities, and structured lecturing versus open inquiry. We believe that MAGDAIRE facilitates pre-service teachers' investigation into ICT-integrated pedagogies. It may be utilised to scaffold pre-service teachers in exploring appropriate pedagogies.

\section{A case study to evaluate the effectiveness of MAGDAIRE}

\section{Context of the study}

MAGDAIRE was employed to run an 18-week long science teacher education course at National Taiwan Normal University (NTNU). NTNU has served as the backbone output source of secondary teachers for Taiwan since 1967 (MOE, 2006). The course was worth 2 credit hours in the secondary teacher education program at NTNU. The panel of teacher trainers consisted of a senior professor with expertise in science education and computer-assisted instruction, a professional designer with expertise in Flash-based courseware development, and a research assistant who holds a science teaching license with experience in Flash-based courseware development. A total of sixteen college students were enrolled in the course. These pre-service teachers had science subjects as their majors, but none of them had a background in computer science. The pre-service teachers voluntarily formed eight groups (two people per group). Each group chose one science topic to develop Flash-based online courseware; each group's topic was different from that of the other groups. The topics included wind, solar and lunar eclipses, cloud, global warming, tide, tsunami, typhoon, and rock. The class met weekly for two hours in a computer lab to complete their projects. The course content is shown in Table 2.

\section{Research questions}

The research questions, within the context of MAGDAIRE, guiding the current study were:

RQ1: Are pre-service teachers' proficiency in Flash knowledge and skills improved after the course?

RQ2: Does the pre-service teachers' TPACK-F transit towards a more connected model that addresses Flash, pedagogy, and content jointly over time? 
Table 2: Course content

\begin{tabular}{|c|c|c|c|c|}
\hline \multicolumn{2}{|c|}{ Phase of MAGDAIRE } & \multirow{2}{*}{$\begin{array}{c}\text { Week } \\
\text { 1st } \\
\text { । } \\
\text { 2nd }\end{array}$} & \multirow[b]{2}{*}{$\begin{array}{l}\text { Assignment and activity } \\
\text { Pre-service teachers are divided into sub-groups } \\
\text { and observe an ampleness of online courseware } \\
\text { that teacher trainers demonstrate. } \\
\text { Teacher trainers lead pre-service teachers in } \\
\text { discussing the design of the demonstrated online } \\
\text { courseware; they engage pre-service teachers in } \\
\text { brainstorming their own online courseware } \\
\text { blueprints. }\end{array}$} & \multirow[b]{2}{*}{\begin{tabular}{|l|}
\multicolumn{1}{|c}{$\begin{array}{c}\text { Data } \\
\text { collection }\end{array}$} \\
Proficiency \\
of Flash \\
knowledge \\
test (PFKT) \\
and \\
Proficiency \\
of Flash skill \\
test (PFST) \\
(week 1)
\end{tabular}} \\
\hline $\begin{array}{l}\text { First } \\
\text { round }\end{array}$ & $\begin{array}{l}\text { Phase I: } \\
\text { Modeled } \\
\text { analysis }\end{array}$ & & & \\
\hline & $\begin{array}{c}\text { Phase II: } \\
\text { Guided } \\
\text { development }\end{array}$ & $\begin{array}{l}\text { 3rd } \\
\text { I } \\
9 \text { th }\end{array}$ & $\begin{array}{l}\text { Teacher trainers introduce the online courseware } \\
\text { design concepts and skills, including: } \\
\text {. Flash: Layer and animation } \\
\text {. Flash: Interactive functions } \\
\text {. Flash: Multimedia integration and playback } \\
\text { Teacher trainers scaffold pre-service teachers to } \\
\text { apply these skills to fulfill their own online } \\
\text { courseware blueprints. At the same time, pre- } \\
\text { service teachers devise relevant activities and } \\
\text { assessments to complement their own online } \\
\text { courseware. }\end{array}$ & $\begin{array}{l}\text { Group } \\
\text { journal } \\
\text { (week 9) }\end{array}$ \\
\hline & $\begin{array}{c}\text { Phase III: } \\
\text { Articulated } \\
\text { implementation }\end{array}$ & 10th & $\begin{array}{l}\text { Pre-service teachers demonstrate their online } \\
\text { courseware prototypes with instructional plans } \\
\text { and explain their design thinking. }\end{array}$ & $\begin{array}{l}\text { Group } \\
\text { journal } \\
\text { (week 10) }\end{array}$ \\
\hline & $\begin{array}{l}\text { Phase IV: } \\
\text { Reflected } \\
\text { evaluation }\end{array}$ & 11th & $\begin{array}{l}\text { Teacher trainers ask pre-service teachers to } \\
\text { evaluate and comment on other groups' } \\
\text { performances and give feedback. }\end{array}$ & \\
\hline \multirow[t]{4}{*}{$\begin{array}{l}\text { Second } \\
\text { round }\end{array}$} & $\begin{array}{l}\text { Phase I: } \\
\text { Modeled } \\
\text { analysis }\end{array}$ & $\begin{array}{c}\text { 12th } \\
\text { । } \\
13 \text { th }\end{array}$ & $\begin{array}{l}\text { Teacher trainers lead pre-service teachers in } \\
\text { discussing how to strengthen the design of online } \\
\text { courseware. }\end{array}$ & \\
\hline & $\begin{array}{l}\text { Phase II: } \\
\text { Guided } \\
\text { development }\end{array}$ & $\begin{array}{l}14 \text { th } \\
\text { । } \\
16 \text { th }\end{array}$ & $\begin{array}{l}\text { Pre-service teachers collaboratively test the ideas } \\
\text { for improving online courseware. } \\
\text { Teacher trainers encourage skilled pre-service } \\
\text { teachers to do peer coaching. }\end{array}$ & $\begin{array}{l}\text { Group } \\
\text { journal } \\
\text { (week 16) }\end{array}$ \\
\hline & $\begin{array}{c}\text { Phase III: } \\
\text { Articulated } \\
\text { implementation }\end{array}$ & 17th & $\begin{array}{l}\text { Pre-service teachers demonstrate their online } \\
\text { courseware prototypes with instructional plans } \\
\text { and explain their design thinking. }\end{array}$ & $\begin{array}{l}\text { Group } \\
\text { journal } \\
\text { (week 17) }\end{array}$ \\
\hline & $\begin{array}{l}\text { Phase IV: } \\
\text { Reflected } \\
\text { evaluation }\end{array}$ & 18th & $\begin{array}{l}\text { Teacher trainers ask pre-service teachers to } \\
\text { evaluate and comment on other groups' } \\
\text { performances and give feedback. }\end{array}$ & $\begin{array}{l}\text { PFKT and } \\
\text { PFST (week } \\
\text { 18) }\end{array}$ \\
\hline
\end{tabular}

\section{Data collection and analysis}

In order to answer RQ1, the Proficiency of Flash Knowledge Test (PFKT) and Proficiency of Flash Skill Test (PFST) were employed. PFKT consisted of 32 true-false items (a total of 32 points). PFST was a practical Flash design task (a total of 10 points). PFKT and PFST were validated by our previous study (Chien et al., 2012), which includes the content and scoring guidelines of the two tests. As specified in Table 2, PFKT and PFST were administrated to the pre-service teachers at the beginning and end of the semester in a pre-post test format. The Kudere-Richardson Formula $20\left(\mathrm{KR}_{20}\right)$ coefficient was used to determine the reliability of data collected by PFKT. A $K_{20}$ of .6 is generally considered an acceptable level (Nunnally, 1978); the estimated $\mathrm{KR}_{20}$ was .9 and .6 for pre-PFKT and 
post-PFKT, respectively. A two-tailed $t$-test statistical analysis was conducted on the mean differences between the pre-service teachers' pre- and post-test scores of PFKT and PFST to examine whether MAGDAIRE improved their proficiency of Flash knowledge and skills. The statistical significance testing was conducted at the alpha= .05 significance level by using Statistical Package for Social Sciences version 15.0.

To answer RQ2, this study traced the development of the pre-service teachers' TPACK$\mathrm{F}$ by collecting and analysing their group journals at different phases of MAGDAIRE. The main themes of the group journal were "What are the problems your group may encounter when you implement your courseware in a classroom for teaching? How do you plan to resolve the stated problem(s)?" As suggested by Koehler et al. (2007), teachers' ideas to solve design problems which they encounter in integrating ICT and teaching reflect the components that dominate their pedagogical reasoning during the process. Therefore, the record of teachers' ideas may function as a proxy to identify the forms of their TPACK. Koehler et al. (2007) analysed the records of teachers' discussions on design problems they encountered when developing a website for online courses, as a way to represent the teachers' development of TPACK.

The current study used group journal writing as an alternative means to induce the pre-service teachers' ideas to solve design problems. As specified in Table 2, each group of the pre-service teachers was engaged in writing group journals at the end of Phase II (first round, week 9), Phase III (first round, week 10), Phase II (second round, week 16), and Phase III (second round, week 17). Thus, a total of 32 group journals (4 phases each for 8 groups) was obtained. Conceptual analysis, which focuses on establishing the existence and frequency of concepts in a text (Berelson, 1971), was applied to categorise the types of design thinking within the pre-service teachers' group journals. The number of occurrences was then computed. The process of conceptual analysis in this study was conducted in the following three steps:

1. The level of analysis on each group's journals was set as "sets of sentences describing a solution to one problem regarding the implementation of group projects." The group journals were carefully reviewed by two researchers and then divided into segments. A total of 128 segments were obtained from the group journals.

2. We developed a TPACK-F coding protocol based on Koehler et al.'s TPACK work (2007) and then coded the segments. The TPACK-F coding protocol can be seen in Table 3. Two researchers used the protocol to analyse each segment and categorise each segment into Content $(\mathrm{C})$, Pedagogy (P), Flash (F), Content pedagogy (CP), Flash content (FC), Flash pedagogy (FP), and Flash content pedagogy (FCP). The inter-rater reliability was estimated by kappa coefficient. The kappa for the two coders was .80 , and the disagreement between the two coders was solved through discussion. The data was re-coded by the same coders two weeks later for enhancing coding reliability. The kappa among the two coding intervals was .84 .

3. A Pearson chi-squared test was conducted to examine whether there was any significant difference in the patterns of pre-service teachers' pedagogical reasoning on the integration of Flash and teaching in different phases of MAGDAIRE. The statistical significance testing was conducted at the alpha $=.05$ significance level. 
Table 3: TPACK-F coding protocol

\begin{tabular}{|c|c|c|}
\hline $\begin{array}{c}\text { Category } \\
\text { (code) }\end{array}$ & Description & Exemplar \\
\hline $\begin{array}{l}\text { Content } \\
\text { (C) }\end{array}$ & $\begin{array}{l}\text { Reasoning on the actual subject } \\
\text { matter that is to be taught, such as } \\
\text { clarifying the facts, concepts, and } \\
\text { theories of the chosen subject } \\
\text { matter. }\end{array}$ & $\begin{array}{l}\text { We have to clarify the explanation for the } \\
\text { greenhouse effect. When solar radiation passes } \\
\text { through the earth's atmosphere, it warms the } \\
\text { planetary surface. The greenhouse gases in the } \\
\text { atmosphere absorb the infrared thermal radiation } \\
\text { emitted from the planetary surface. Furthermore, } \\
\text { the greenhouse effect already existed before the } \\
\text { occurrence of the so-called global warming. }\end{array}$ \\
\hline $\begin{array}{l}\text { Pedagogy } \\
\text { (P) }\end{array}$ & $\begin{array}{l}\text { Reasoning on the processes and } \\
\text { methods of teaching and learning; } \\
\text { also, how it encompasses overall } \\
\text { educational purposes, values and } \\
\text { aims, such as arranging students' } \\
\text { learning steps. }\end{array}$ & $\begin{array}{l}\text { We should administer a test to students by the } \\
\text { end of the course. It can help us to understand } \\
\text { students' learning progress and thus offer us } \\
\text { information to give students appropriate } \\
\text { feedback. }\end{array}$ \\
\hline $\begin{array}{l}\text { Flash } \\
\text { (F) }\end{array}$ & $\begin{array}{l}\text { Reasoning on the use of Flash but } \\
\text { not specifically related to the } \\
\text { chosen subject matter or teaching } \\
\text { strategies, such as the operation of } \\
\text { one particular function of Flash. }\end{array}$ & $\begin{array}{l}\text { The animation may suddenly break off while } \\
\text { playing. Maybe we should use the frame-by- } \\
\text { frame approach to compile the animation. }\end{array}$ \\
\hline $\begin{array}{l}\text { Content } \\
\text { pedagogy } \\
\text { (CP) }\end{array}$ & $\begin{array}{l}\text { Reasoning on how particular } \\
\text { aspects of a subject matter are } \\
\text { organised, adapted, and } \\
\text { represented for instruction, such } \\
\text { as specifying one teaching } \\
\text { strategy to complement one } \\
\text { particular concept of the chosen } \\
\text { subject matter. }\end{array}$ & $\begin{array}{l}\text { By comparing with other subjects in the domain } \\
\text { of earth science, the learning unit of rocks puts } \\
\text { more emphasis on students memorising the facts. } \\
\text { In addition to introducing the characteristics of } \\
\text { varied kinds of rocks and Moh's Hardness scale, } \\
\text { we should encourage students to compare the } \\
\text { differences in the hardness, crystal system, crystal } \\
\text { class, and streak between minerals to enhance } \\
\text { their learning motivation. }\end{array}$ \\
\hline $\begin{array}{l}\text { Flash } \\
\text { content } \\
\text { (FC) }\end{array}$ & $\begin{array}{l}\text { Reasoning on how the chosen } \\
\text { subject matter might be shaped by } \\
\text { the application of Flash, such as } \\
\text { leveraging one particular function } \\
\text { of Flash to present the chosen } \\
\text { subject matter. }\end{array}$ & $\begin{array}{l}\text { The pictures of clouds can be embedded with } \\
\text { more detailed information by utilising Action } \\
\text { Script. We attempt to revise the scripts to make } \\
\text { the cloud characteristics, such as cloud } \\
\text { classification and cloud height which will appear } \\
\text { when the cursor is moved onto the cloud pictures. }\end{array}$ \\
\hline $\begin{array}{l}\text { Flash } \\
\text { pedagogy } \\
\text { (FP) }\end{array}$ & $\begin{array}{l}\text { Reasoning on how teaching as } \\
\text { well as learning might be changed } \\
\text { by the use of Flash, such as } \\
\text { leveraging one particular function } \\
\text { of Flash to support one particular } \\
\text { teaching strategy. }\end{array}$ & $\begin{array}{l}\text { The online testing system should be added, with } \\
\text { Action Script, to count students' scores. If a } \\
\text { student types in wrong answers to a question too } \\
\text { many times, the system will automatically force } \\
\text { him/ her to view the animation which explains } \\
\text { the concept of that question. }\end{array}$ \\
\hline $\begin{array}{l}\text { Flash } \\
\text { content } \\
\text { pedagogy } \\
(\text { FCP) }\end{array}$ & $\begin{array}{l}\text { Reasoning on how the chosen } \\
\text { subject matter might be shaped by } \\
\text { the application of Flash and the } \\
\text { impact of such applications on } \\
\text { teaching methods, such as } \\
\text { leveraging one particular function } \\
\text { of Flash to present the chosen } \\
\text { subject matter and support one } \\
\text { particular teaching strategy. }\end{array}$ & $\begin{array}{l}\text { We plan to add interactive functions into the } \\
\text { animation depicting sea waves, to allow students } \\
\text { manipulate the variations in the water depth } \\
\text { along the coastline. By this means, students can } \\
\text { test their hypotheses of the relation between } \\
\text { water depth and wave speed, and then discuss } \\
\text { the data they obtain from the animation with } \\
\text { peers. It will facilitate students in exploring the } \\
\text { relationship between water depth and wave } \\
\text { speed. It also helps to explain the difference } \\
\text { between deep and shallow waves to students. }\end{array}$ \\
\hline
\end{tabular}




\section{Findings and discussion}

Advancement in proficiency of Flash knowledge and skills

As shown in Table 4 , the results of two-tailed paired $t$-test analysis reveal that there are statistically significant differences in their pre-post scores on both PFKT and PFST $(p<$ .001 for PFKT and $p<.001$ for PFST). The effect sizes computed from the $t$-test analysis on the pre-service teachers' pre-post test scores are beyond the large magnitude $(d=2.2$ for PFKT and $d=1.6$ for PFST). Moreover, by examining the pre-service teachers' Flashbased online courseware collected at the end of the course, we found that all of their Flash-based online courseware can be operated by users on personal computers without any functional errors. The screenshots of three samples of the pre-service teachers' finished products are presented in Figure 2. The quality of the pre-service teachers' courseware suggests that the pre-service teachers acquire commendable technical knowledge and skills of Flash through the MAGDAIRE model. These proficiencies enabled them to customise applicable Flash-based online courseware. Overall, in a practical sense, MAGDAIRE can significantly enhance pre-service teachers' Flash knowledge and skills.

Table 4: Comparisons between pre-service teachers' pre-test and post-test scores

\begin{tabular}{|c|c|c|c|c|c|c|c|c|c|}
\hline \multirow{2}{*}{ Test } & \multicolumn{3}{|c|}{ Pre-test scores } & \multicolumn{3}{c|}{ Post-test scores } & \multicolumn{3}{c|}{ Two-tailed paired $t$-test } \\
\cline { 2 - 11 } & $n$ & $M$ & $S D$ & $n$ & $M$ & $S D$ & $t$ & $p$ & $d$ \\
\hline PFKT & 16 & 13.7 & 4.8 & 16 & 22.6 & 4.1 & 8.64 & $.000^{*}$ & 2.2 \\
\hline PFST & 16 & 4.3 & 1.1 & 16 & 7.2 & 1.7 & 6.20 & $.000^{*}$ & 1.6 \\
\hline
\end{tabular}
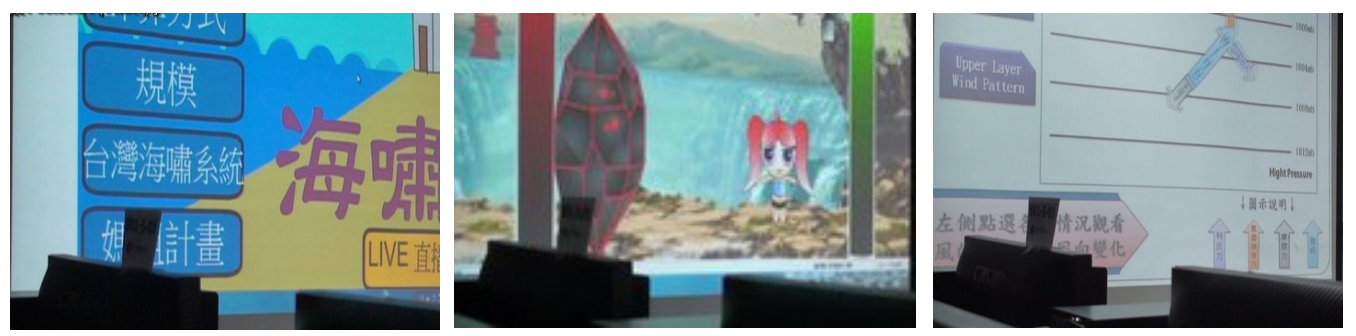

Figure 2: Screenshots of pre-service teachers' Flash-based online science courseware

\section{Development in TPACK-F}

Table 5 presents the crosstabs statistics of the coded segments by phases. As shown in Table 5, the data distribution violates the assumption of the chi-squared test because there are 19 cells with frequency lower than 5, below the expected value. Therefore, we combine the predefined categories to facilitate the computation of a chi-squared test. The categories $\mathrm{C}, \mathrm{P}$, and $\mathrm{F}$ are combined into a new category called isolated concept, whereas the categories $\mathrm{CP}, \mathrm{FC}, \mathrm{FP}$, and FCP are combined into another new category called integrated concept. As shown in Table 6, the results of the chi-squared test on the combined categories indicate that there is statistically significant difference in the patterns of pre-service teacher' reasoning in the four phases $\left(\chi^{2}[3]=31.68, p<.001\right.$, Cramer's $V=0.5$, large effect size); and no cell has expected count lower than five. We further examine the standard residuals in Table 6 to determine the cells with significant differences. The significance level of post-hoc analysis was adjusted to $.0083(.05 / 6)$ by applying Bonferroni correction. The results reveal that the occurrence of isolated concepts in the pre-service teachers' reasoning on design problems (i.e., $\mathrm{C}, \mathrm{P}$, or F) is significantly higher than the expected value $(p<.0083)$ at the end of Phase II (first 
round). The occurrence of integrated concepts (i.e., CP, FC, FP, or FCP) is significantly lower than the expected value $(p<.0083)$ at the end of Phase II (round 1). No significant differences can be found in Phase III (round 1), Phase II (round two), and Phase III (round 2).

Table 5: Crosstabs statistics of the distribution of coded segments over phases

\begin{tabular}{|c|c|c|c|c|c|c|}
\hline & \multirow[b]{2}{*}{ Concept } & \multicolumn{4}{|c|}{ Phase } & \multirow[b]{2}{*}{ Total } \\
\hline & & $\begin{array}{l}\text { Phase II } \\
\text { (round 1) }\end{array}$ & $\begin{array}{l}\text { Phase III } \\
\text { (round 1) }\end{array}$ & $\begin{array}{l}\text { Phase II } \\
\text { (round 2) }\end{array}$ & $\begin{array}{l}\text { Phase III } \\
\text { (round 2) }\end{array}$ & \\
\hline \multirow[t]{4}{*}{$\mathrm{C}$} & Count & $6(18.2 \%)(\mathrm{a})$ & $3(8.6 \%)$ & $2(7.1 \%)$ & $0(.0 \%)$ & 11 \\
\hline & Expected count & 2.8 & 3.0 & 2.4 & 2.8 & 11.0 \\
\hline & Residual & 3.2 & .0 & -.4 & -2.8 & \\
\hline & Std. residual & 1.9 & .0 & -.3 & -1.7 & \\
\hline \multirow[t]{4}{*}{$\mathrm{P}$} & Count & $6(18.2 \%)$ & $2(5.7 \%)$ & $2(7.1 \%)$ & $0(.0 \%)$ & 10 \\
\hline & Expected count & 2.6 & 2.7 & 2.2 & 2.5 & 10.0 \\
\hline & Residual & 3.4 & -.7 & -.2 & -2.5 & \\
\hline & Std. residual & 2.1 & -.4 & -.1 & -1.6 & \\
\hline \multirow[t]{4}{*}{ F } & Count & $13(39.4 \%)$ & $4(11.4 \%)$ & $0(.0 \%)$ & $8(25.0 \%)$ & 25 \\
\hline & Expected count & 6.4 & 6.8 & 5.5 & 6.3 & 25.0 \\
\hline & Residual & 6.6 & -2.8 & -5.5 & 1.8 & \\
\hline & Std. residual & 2.6 & -1.1 & -2.3 & .7 & \\
\hline \multirow[t]{4}{*}{$\mathrm{CP}$} & Count & $4(12.1 \%)$ & $4(11.4 \%)$ & $2(7.1 \%)$ & $1(3.1 \%)$ & 11 \\
\hline & Expected count & 2.8 & 3.0 & 2.4 & 2.8 & 11.0 \\
\hline & Residual & 1.2 & 1.0 & -.4 & -1.8 & \\
\hline & Std. residual & .7 & .6 & -.3 & -1.1 & \\
\hline \multirow[t]{4}{*}{$\mathrm{FC}$} & Count & $2(6.1 \%)$ & $8(22.9 \%)$ & $2(7.1 \%)$ & $4(12.5 \%)$ & 16 \\
\hline & Expected count & 4.1 & 4.4 & 3.5 & 4.0 & 16.0 \\
\hline & Residual & -2.1 & 3.6 & -1.5 & .0 & \\
\hline & Std. residual & -1.0 & 1.7 & -.8 & .0 & \\
\hline \multirow[t]{4}{*}{$\mathrm{FP}$} & Count & $2(6.1 \%)$ & $10(28.6 \%)$ & $14(50.0 \%)$ & $10(31.3 \%)$ & 36 \\
\hline & Expected count & 9.3 & 9.8 & 7.9 & 9.0 & 36.0 \\
\hline & Residual & -7.3 & .2 & 6.1 & 1.0 & \\
\hline & Std. Residual & -2.4 & .0 & 2.2 & .3 & \\
\hline \multirow[t]{4}{*}{ FCP } & Count & $0(.0 \%)$ & $4(11.4 \%)$ & $6(21.4 \%)$ & $9(28.1 \%)$ & 19 \\
\hline & Expected count & 4.9 & 5.2 & 4.2 & 4.8 & 19.0 \\
\hline & Residual & -4.9 & -1.2 & 1.8 & 4.3 & \\
\hline & Std. residual & -2.2 & -.5 & .9 & 2.0 & \\
\hline \multirow[t]{2}{*}{ Total } & Count & $33(100.0 \%)$ & $35(100.0 \%)$ & $28(100.0 \%)$ & $32(100.0 \%)$ & 128 \\
\hline & Expected count & 33.0 & 35.0 & 28.0 & 32.0 & 128.0 \\
\hline
\end{tabular}

a. $\%$ within phase.

Overall, the results indicate that the pre-service teachers' TPACK-F showed profound changes towards a more connected model by the end of Phase III (round 1); by comparing with Phase II (round 1), the percentage of the summation of integrated concepts (i.e., CP, FC, FP, and FCP) raised from $24.2 \%$ to $74.3 \%$ at the end of Phase III (round 1). Moreover, such connected model of TPACK-F was sustained in the preservice teachers' reasoning at the end of Phase II (round 2) and Phase III (round 2); the percentages of the summation of integrated concepts were relatively high $(85.7 \%$ for Phase II (round 2) and 75.0\% for Phase III (round 2). 
Table 6: Crosstabs statistics of the distribution of combined categories over phases

\begin{tabular}{|c|c|c|c|c|c|c|}
\hline & \multirow[b]{2}{*}{ Concept } & \multicolumn{4}{|c|}{ Phase } & \multirow[b]{2}{*}{ Total } \\
\hline & & $\begin{array}{l}\text { Phase II } \\
\text { (round 1) }\end{array}$ & $\begin{array}{l}\text { Phase III } \\
\text { (round 1) }\end{array}$ & $\begin{array}{c}\text { Phase II } \\
\text { (round 2) }\end{array}$ & $\begin{array}{l}\text { Phase III } \\
\text { (round 2) }\end{array}$ & \\
\hline \multirow[t]{4}{*}{ Isolated } & Count & $25(75.8 \%)(\mathrm{a})$ & $9(25.7 \%)$ & $4(14.3 \%)$ & $8(25.0 \%)$ & 52 \\
\hline & Expected count & 11.9 & 12.6 & 10.1 & 11.5 & 52.0 \\
\hline & Residual & 13.1 & -3.6 & -6.1 & -3.5 & \\
\hline & Std. residual & $3.8^{*}$ & -1.0 & -1.9 & -1.0 & \\
\hline \multirow{4}{*}{ Integrated } & Count & $8(24.2 \%)$ & $26(74.3 \%)$ & $24(85.7 \%)$ & $24(75.0 \%)$ & 76 \\
\hline & Expected count & 21.1 & 22.4 & 17.9 & 20.5 & 76.0 \\
\hline & Residual & -13.1 & 3.6 & 6.1 & 3.5 & \\
\hline & Std. residual & $-2.9^{*}$ & .8 & 1.4 & .8 & \\
\hline \multirow[t]{2}{*}{ Total } & Count & $33(100.0 \%)$ & $35(100.0 \%)$ & $28(100.0 \%)$ & $32(100.0 \%)$ & 128 \\
\hline & Expected count & 33.0 & 35.0 & 28.0 & 32.0 & 128.0 \\
\hline
\end{tabular}

a. $\%$ within phase; ${ }^{*} p<.0083$

The results suggest that only engaging pre-service teacher in designing Flash-based lessons is not sufficient to develop their TPACK-F. Before Phase III (round 1), the TPACK-F was determined by the teacher trainers and was delivered to the pre-service teachers. The pre-service teachers were expected to learn this knowledge and apply it to build Flash-based courseware and design their Flash-integrated instructional plans. The major role of the pre-service teachers was that of the passive receiver of TPACK-F. In this stage, the pre-service teachers mainly treated content, pedagogy, and Flash as isolated elements of Flash-integrated teaching; the coded segments of C, P, and F occupied the pre-service teachers' group journals (a total of $75.8 \%$ ). Especially, the Flash-only reasoning (F) dominated the pre-service teachers' design thinking.

However, one week later (i.e., at the end of Phase III (round 1)), there was a significant shift in the presence of Flash-related reasoning in the group journals. Flash was addressed jointly with pedagogy $(\mathrm{FP}=28.6 \%)$ or with content $(\mathrm{FC}=22.9 \%)$, rather than being thought of in the isolated form $(\mathrm{F}=11.4 \%)$. Moreover, Flash became integrated with both content and pedagogy at the end of this phase $(\mathrm{FCP}=11.4 \%)$. The plausible reason is that Phase III (round 1) forced each pre-service teacher to consider what elements were critical to successful and unsuccessful Flash-integrated teaching. In this stage, the pre-service teachers were not only receivers of TPACK-F but also generators of TPACK-F. This process made the pre-service teachers rethink why and how they used the functionalities of Flash to accomplish pedagogical goals by comparing their own performance with that of others. Thus it facilitated the preservice teachers in re-examining the connection between the affordances of Flash and teaching to revise their solutions to design problems. By examining the content of the coded segments, it is found that at the end of Phase III (round 1), the pre-service teachers tended to use Flash to complement the solutions related to content and/or pedagogy issues which they previously proposed in Phase II (round 1).

An example of the transition from P to FP can be found in Ken's group. Ken's group stated one concern for learning evaluation at the end of Phase II (round 1), "We should add some tests into the curriculum. Only by this means, we are able to understand students' learning progress and provide them with aids in conquering learning difficulties" (coded as P). Ken's group then tended to leverage the Action Script of Flash to enhance the process of learning evaluation at the end of Phase III (round 1), "we can incorporate the automatic response mechanism into our tests. It not only helps us to 
evaluate students' learning progress but also promotes the interactivity of the evaluation - it may enhance students' motivation" (coded as FP). Another case of transition from $C$ to FC is that Tim's group clarified their teaching focus on the movement of winds at the end of Phase II (round 1), "We should emphasise some situations in which the movement of winds is affected by Coriolis force. Upper-air winds blow parallel to the isobars and reflect a balance between the pressure-gradient force and the Coriolis effect" (coded as C); Tim's group decided to draw on the incorporation of Action Script and animations to better visualise the chosen subject matter at the end of Phase III (round 1), "we plan to enable the wind direction, depicted in the animation, to be manipulated by typing in pressure values and switching the existence of Coriolis force" (coded as FC).

A case of the transition from FC to FCP from Albert's group concerned the strategy for teaching tsunami at the end of Phase II (round 1), "Students may encounter great difficulties in recognising the differences between tsunami waves and normal sea waves. We have to clarify the difference between these two types of waves in class" (codes as CP). They then considered using animations to enhance the pedagogical technique for teaching tsunami at the end of Phase III (round 1), "We want to use an animation to present the profiles of both tsunami and normal sea waves. It helps students to compare the differences between tsunami and normal sea waves, in terms of both period and speed" (coded as FCP).

The aforementioned trend is also found across Phase II (round 2) and Phase III (round 2). In addition, the pre-service teachers tended to deliberate the niches of Flash-based resources to empower their pedagogies (i.e., the transition from FC to FCP) at the end of Phase II (round 2) and Phase III (round 2). An example of this may be seen when Tim's group decided to reshape their animation about the movement of winds at the end of Phase III (round 1), "...to enable the wind direction to be manipulated by typing in pressure values and switching the existence of Coriolis force" (coded as FC). Tim's group then relied on this animation to support students' inquiry at the end of Phase III (round 2), "...by manipulating the pressure-gradient force, Coriolis force, and friction force in the animation, students are able to test their hypotheses about the wind movement and demonstrate their experiments to peers and the teacher" (coded as FCP). However, the pre-service teachers rarely identified the impacts of the Flashintegrated pedagogies on their subject matter (i.e., the transition from FP to FCP). The plausible reason is that the Flash-integrated pedagogies, which the pre-service teachers proposed, are inherently not constrained by the characteristics of their subject matter. For instance, the incorporation of the automatic response mechanism into assessments is, in general, applicable to any subject matter.

An interesting phenomenon is found that a peak of Flash-only reasoning emerges from Phase III (round 2) $(\mathrm{F}=25 \%)$. By examining the content of the segments coded as F across four phases, we found that the Flash issues, which concerned the pre-service teachers in Phase III (round 2), were more advanced Flash subjects than those of the other three phases. The F codes of Phase III (round 2) mainly focused on the programming of Action Script, as one group stated at the end of Phase III (round 2), "The chess of the losers in the game should be removed away from the chessboard. We should program Action Script to hide the chess of the players who are eliminated through competition" (coded as F). Those of the previous phases focused on animation compilation, "...using the frame-by-frame approach to compile the animation" (coded as F). The finding reveals that, by the end of MAGDAIRE, the pre-service teachers tended to enhance their courseware with advanced Flash knowledge and skills. This 
implies that the pre-service teachers' Flash knowledge and skills were promoted to a higher level. In addition, it also illuminates the importance of the technical supports to sustain pre-service teachers' inquiry into advanced Flash knowledge and skills for complementing teaching practices after the course.

\section{Limitations}

Some concerns about the power of statistical significance testing may be raised because the sample size involved in this study is rather small. As a matter of fact, a small sample size is inherently more difficult to achieve statistical significance than a large one (Daniel, 1998; McLean \& Ernest, 1998). However, the effect sizes reported in this study all attain a large magnitude. It suggests that the statistically significant differences reported in this study have practical significance. Moreover, the findings will be much easier to obtain statistical significance and be replicated in a larger sample size. It also should be noted that the claims drawn from the study could be weakened if the coding scheme was flawed or the researchers made misjudgments when coding the qualitative data. However, the coding scheme was cautiously developed from a previous research (Koehler et al., 2007). We also attempted to minimise subjectivity and enhance reliability while coding the collected data. We suggest future research to conduct relational analyses on the interaction between ICT, pedagogy, and content in teachers' reasoning. Such analyses will be very valuable to the field of TPACK research. The current study reports possible pathways for isolated concepts of TPACK-F to evolve into integrated concepts of TPACK-F. These pathways may be helpful to build a framework for future studies to conduct relational analyses on teachers' development of TPACK. However, additional data should be collected to confirm speculations on these pathways. For example, interviews with teachers must be conducted, to clarify the relationships between the ideas which they wrote down in group journals during different phases of MAGDAIRE. This is one of the tasks planned for while implementing MAGDAIRE in the next round in 2012.

\section{Conclusion and recommendations}

The findings of the current study echo with our pilot study (Chien et al., 2012) that MAGDAIRE can significantly enhance pre-service teachers' proficiency in Flash knowledge and skills. Moreover, the current study further indicates that MAGDAIRE can facilitate pre-service teachers' TPACK-F development towards a more connected model that addresses Flash, pedagogy, and content jointly. Some may doubt the findings of the current study because it seems quite natural for pre-service teachers to see a better connection between Flash, pedagogy, and content as they learn more and have more experience with Flash. Though this presumption is rational, it is not supported by previous studies. For instance, Koehler et al. (2007) used the TPACK framework to analyse the discussion during a design seminar in which faculty members worked in conjunction with masters students to develop online courses. The analysis on the design-talk of two groups (i.e., the Adams Family group and the Jackrabbits group) showed divergent patterns from a similar design-based problem solving experience. When dealing with design problems within a semester-long period, the Adams Family group showed profound changes towards a more connected model, in which ICT was jointly considered with content and/or pedagogy. On the other hand, the Jackrabbits group did not show such changes. Koehler et al. (2007) concluded that the learning technology by design approach can enable the growth of TPACK to occur, but did not guarantee it. However, this study into the MAGDAIRE model shows a general growth of the pre-service teachers' TPACK-F across groups. 
The plausible reason is that MAGDAIRE strengthens and complements the original version of the learning by design approach. The facets of cognitive apprenticeship put in place in MAGDAIRE may further facilitate pre-service teachers to articulate and modify their TPACK-F, and thus can foster pre-service teachers' better development of TPACK-F. Especially, engaging pre-service teachers in co-constructing TPACK-F is found to be a critical mechanism for deepening their recognition of the interplays between Flash, pedagogy, and content.

Further suggested potential accompaniments when employing MAGDAIRE to enhance teacher education courses are as follows. Firstly, encourage pre-service teachers to record their design thinking. We acknowledge that asking the pre-service teachers to collaboratively turn in their group journals may function as an intervention of the reported study. This strategy may facilitate pre-service teachers to become aware of why and how they choose solutions to pedagogical problems. Moreover, this strategy seems to have positive impacts on pre-service teachers' reasoning between ICT, content, and pedagogy. The solutions that the pre-service teachers described in their group journals reflected more deepened reasoning over time in the study.

Secondly, we also advocate supporting pre-service teachers' inquiry into ICT both during and after the course. Pre-service teachers certainly will run into technical problems that they find difficult to solve independently after classes, due to the limited time of weekly formal courses. Thus there is a need to provide pre-service teachers with online platforms to discuss with experts and peers what they experience individually. The cases solved through the collaboration between experts and preservice teachers can be recorded online, so that they can be a reference for future research. As revealed by the reported study, pre-service teachers tend to explore more advanced ICT skills to complement their teaching practices (i.e., the programming related to Action Script) by the end of MGADAIRE. Therefore, sustained technical support is vital to encourage pre-service teachers to explore the pedagogical rationale of ICT use. We have currently assigned a research assistant as a part-time facilitator to help the pre-service teachers to overcome Flash-related issues even after they have passed the course.

\section{Acknowledgments}

The authors wish to thank the Aim for the Top University (ATU) project of the National Taiwan Normal University (NTNU) for financing this study. The authors gratefully acknowledge the assistance of Chun-Chieh Huang and Terrence Wong. The authors also thank anonymous reviewers for valuable comments.

\section{References}

Adobe (2010). Flash player statistics. [viewed 20 Nov 2010]. http: / / www.adobe.com/ products / flashruntimes/ statistics.html

Angeli, C. (2005). Transforming a teacher education method course through technology: Effects on preservice teachers' technology competency. Computers $\mathcal{E}$ Education, 45(4), 383-398. http: / / dx.doi.org/10.1016/j.compedu.2004.06.002

Angeli, C. \& Valanides, N. (2009). Epistemological and methodological issues for the conceptualization, development, and assessment of ICT-TPCK: Advances in technological pedagogical content knowledge (TPCK). Computers \& Education, 52(1), 154-168. http: / / dx.doi.org/10.1016/j.compedu.2008.07.006 
Berelson, B. (1971). Content analysis in communication research. New York: Hafner Publishing Company.

Chang, C. Y. (2003). Teaching earth sciences: Should we implement teacher-directed or studentcontrolled CAI in the secondary classroom? International Journal of Science Education, 25(4), 427-438. http: / / dx.doi.org/10.1080/09500690210145701

Chang, C. Y. \& Tsai, C. C. (2005). The interplay between different forms of CAI and students' preferences of learning environment in the secondary science class. Science Education, 89(5), 707-724. http:/ / dx.doi.org/10.1002/ sce.20072

Chien, Y. T. \& Chang, C. Y. (2012). Comparison of different instructional multimedia designs for improving student science-process skill learning. Journal of Science Education and Technology, 21(1), 106-113.

Chien, Y. T., Chang, C. Y., Yeh, T. K. \& Chang, K. E. (2012). Engaging pre-service science teachers to act as active designers of technology integration: A MAGDAIRE framework. Teaching and Teacher Education, 28(4), 578-588. http:/ / dx.doi.org/10.1016/j.tate.2011.12.005

Clark, C. M. \& Yinger, R. J. (1987). Teacher planning. In D. C. Berliner \& B. Rosenshine (Eds.), Talks to teachers. New York: Lane Akers, Inc.

Collins, A. (1988). Cognitive apprenticeship and instructional technology: Technical report. Cambridge, MA: Bolt Beranek and Newman. http: / / www.eric.ed.gov / ERICWebPortal/contentdelivery / servlet/ERICServlet?accno=ED331465

Daniel, L. G. (1998). Statistical significance testing: A historical overview of misuse and misinterpretation with implication for the editorial policies of educational journals. Research in the Schools, 5(2), 23-32. http:/ / citeseerx.ist.psu.edu/viewdoc/summary?doi=10.1.1.122.4807

Enochsson, A. \& Rizza, C. (2009). ICT in initial teacher training: Research review. OECD Publishing. http: / / www.oecd-ilibrary.org/ education/ict-in-initial-teacher-training-researchreview_220502872611

Govender, D. \& Govender, I. (2009). The relationship between information and communications technology (ICT) integration and teachers' self-efficacy beliefs about ICT. Education As Change, 13(1), 153-165. http:/ / dx.doi.org/10.1080/16823200902943346

International Society for Technology in Education (2008). National educational technology standards and performance indicators for teachers. Eugene, OR: International Society for Technology in Education. http:/ / www.iste.org/standards / nets-for-teachers.aspx

Jang, S. J. (2008). The effects of integrating technology, observation and writing into a teacher education method course. Computers \& Education, 50(3), 853-865. http:/ / dx.doi.org/10.1016/j.compedu.2006.09.002

Jang, S. J. \& Chen, K.-C. (2010). From PCK to TPACK: Developing a transformative model for pre-service science teachers. Journal of Science Education and Technology, 19(6), 553-564. http: / / dx.doi.org/10.1007/ s10956-010-9222-y

Koehler, M. J., Mishra, P. \& Yahya, K. (2007). Tracing the development of teacher knowledge in a design seminar: Integrating content, pedagogy and technology. Computers \& Education, 49(3), 740-762. http:/ / dx.doi.org/10.1016/j.compedu.2005.11.012

Lee, M. H. \& Tsai, C. C. (2010). Exploring teachers' perceived self efficacy and technological pedagogical content knowledge with respect to educational use of the World Wide Web. Instructional Science, 38(1), 1-21. http: / / dx.doi.org/10.1007/ s11251-008-9075-4

Mahdizadeh, H., Biemans, H. \& Mulder, M. (2008). Determining factors of the use of e-learning environments by university teachers. Computers $\mathcal{E}$ Education, 51(1), 142-154. http:/ / dx.doi.org/10.1016/j.compedu.2007.04.004 
McLean, J. E. \& Ernest, J. M. (1998). The role of statistical significance testing in educational research. Research in the Schools, 5(2), 15-22.

Mishra, P. \& Koehler, M. J. (2006). Technological pedagogical content knowledge: A framework for teacher knowledge. Teachers College Record, 108(6), 1017-1054. http: / / www.tcrecord.org/ Content.asp?ContentID=12516

MOE (2006). Important teacher cultivation policy. Taipei, Taiwan: MOE.

MOE (2008a). Information education report. Taipei, Taiwan: MOE.

MOE (2008b). Primary and secondary school information education white paper. Taipei, Taiwan: MOE.

Niess, M. L. (2005). Preparing teachers to teach science and mathematics with technology: Developing a technology pedagogical content knowledge. Teaching and Teacher Education, 21, 509-253. http:/ / www.citejournal.org/vol8/iss4/mathematics/article1.cfm

Nunnally, J. C. (1978). Psychometric theory. New York: Oxford University Press.

Organization for Economic Cooperation and Development (2010). Inspired by technology, driven by pedagogy: A systemic approach to technology-based school innovations. Organization for Economic Cooperation and Development Publishing. http:/ / www.oecd.org/ edu/ceri/inspiredby technologydrivenbypedagogyasystemicapproachtotechnology-basedschoolinnovations.htm

Sørebø, Ø., Halvari, H., Gulli, V. F. \& Kristiansen, R. (2009). The role of self-determination theory in explaining teachers' motivation to continue to use e-learning technology. Computers $\mathcal{E}$ Education, 53(4), 1177-1187. http: / / dx.doi.org/10.1016/j.compedu.2009.06.001

Wilson, E. K. (2003). Preservice secondary social studies teachers and technology integration: What do they think and do in their field experiences. Journal of Computing in Teacher Education, 20(1), 29-39.

Authors: Dr Chun-Yen Chang (corresponding author), Professor and Director Graduate Institute of Science Education, National Taiwan Normal University, Taiwan Science Education Center, National Taiwan Normal University, Taiwan Department of Earth Sciences, National Taiwan Normal University, Taiwan Email: changcy@ntnu.edu.tw Website: http:/ / w1.ceels.org/chunyen/

Yu-Ta Chien, PhD student, Graduate Institute of Science Education National Taiwan Normal University, Taiwan. Email: yutachien@ntnu.edu.tw

Dr Yueh-Hsia Chang, Assistant Research Fellow, Science Education Center National Taiwan Normal University, Taiwan. Email: yueh@ntnu.edu.tw

Dr Chen-Yung Lin, Professor and Dean

Graduate Institute of Science Education, National Taiwan Normal University, Taiwan Office of Teacher Education and Careers Service, National Taiwan Normal University Department of Life Science, National Taiwan Normal University, Taiwan Email: 1cy@ntnu.edu.tw

Chun-Yen Chang and Yu-Ta Chien contributed equally to this work.

Please cite as: Chang, C.-Y., Chien, Y.-T., Chang, Y.-H. \& Lin, C.-Y. (2012). MAGDAIRE: A model to foster pre-service teachers' ability in integrating ICT and teaching in Taiwan. In C. P. Lim \& C. S. Chai (Eds), Building the ICT capacity of the next generation of teachers in Asia. Australasian Journal of Educational Technology, 28(Special issue, 6), 983-999. http: / / www.ascilite.org.au / ajet/ajet28/ chang-cy.html 